\title{
Unwholesome Food Revisited
}

\section{Sabnis M*}

Jeevanrekha Ayurved, India

\section{Short Communication}

Volume 5 Issue 1

Received Date: January 06, 2021

Published Date: January 26, 2021

DOI: $10.23880 /$ jonam-16000294

Maharashtra India, Email: Jeevanrekha1996@rediffmail.com

\section{Short Communication}

Diet is a point of concern in all human beings since ages all over the globe. Different traditions have different dietary practices which have a varied impact on the health of people. Though Ayurved has emphasized more on perfection of food habits and have identified food as the most important cause to create disease, still food remains as the center point of joy and happiness among the people all over the world. It is very evident in Ayurved text as food has been claimed as body fuel and one should be highly choosey while selecting food for consumption. In fact food consumption should be super personal concept as everybody's phenotype make up is different. So, it's very much true that one size does not fit all regarding food and eating habits [1].

Not only the food but the food processing's, food combination, food cultivation also plays important role to maintain homeostasis and healthy body tissues. It's highly unfortunate that globalization of food has made easy availability of global food in kitchen at the same time globalization of food has also imparted untoward effects in health maintenance. Similarly accelerated harvesting might also have an impact on disease creation [2]. Such type of food may lead to many metabolo immune disorders which have proved to be dreadful in mankind. High processing of food which is liked my many teen agers also leads to change in their chemical composition leading to initiation of many disease process. Such type of food can lead to allergic complains to malignancy and many more. It's regrettable that many of the treating physicians are unaware of these facts and specific diet controls are not advised along with the treatment.

Charak has clearly mentioned that the impact of food is much greater than the impact of medicine in regular practice. It has also been quoted as wrong food consumption is the prime important factor to create disease [3]. Hence proper diet controls are of prime importance while treating the pathology of diseases. Acharya Kashyap has clearly mentioned food as Mahaaushadha that is super medicine [4].

While looking towards the causes of disease mentioned in Ayurved there are certain food categories which has occurred frequently in Ayurved ancient text which are said to be important cause of disease. These food categories must be properly addressed and interpreted and should me made simple to understand to a common man as well the treating faculties. Certain food classifications are elaborated in the text which has a big role in creating disease process. It is a need of today's era to explore these types of food in the light of bio chemistry, nutrition, epigenetic which will be easy to understand to contemporary medical personals.

These Classifications are

- Virrudha Ahar

- Abhishyandi Ahar

- Gramya Ahar

- Malina ahar

These types of food are highly promoters of many pathological processes in the body and controlling these types of food may help to halt the disease process in the body.

\section{$>$ Virrudha ahar}

Virrudha ahar is said to be incompatible diet which is not very correct. This limits the scope of virrudha ahar. It has been clearly mentioned that food or food combinations or certain food processing, wrong portion size, wrong time of food consumption, food which is not consumed considering ones prakruti or phenotype are all viruddha. The type of food which restricts proper growth and nutrition of the tissue is called as virrudha ahar. It is further explained that such types of food when consumed may lead to mal absorption and mal metabolism creating wrong metabolites which get deposited in the tissues and are not able to expel from tissue or cell leading to many serious disease process [5]. These types of 


\section{Journal of Natural \& Ayurvedic Medicine}

harmful activities of the food should be explored chemically. One of the important concerns is to identify wrong and deadly combinations which are used in day to day practice and are not been identified as deadly combinations. We can take example of food which is supposed to be healthy like fruit juices, sausages or omlets in morning breakfast. These types of food stuffs may be over loaded with micro nutrients but prove to be harmful when considered its bio chemical impacts on tissue consumed together. Only fruit juices alone for certain people can also prove to be dangerous because of its high EFF (effective free fructose). Fruits are considered to be most healthy food and are consumed in a regular fashion even by people under metabolic syndrome or Syndrome X. There are many harmful combination were people are not aware or do not believe due to lack of scientific explanations. There are many food detriments which can be explored in scientific manner. If such ill impacts of food or food combinations are studied and elaborated in scientific manner we can prevent many non-communicable metabolic disorders.

\section{$>$ Abhishyandi Ahar}

Abhishyandi ahar is again a classification of food which blocks the micro channels of the body and prevents proper digestion of food leading to improper food metabolism. This can lead to mal nutrition of tissues leading to laxity in tissue and mal function of tissues [6]. Such type of food can create swelling at cellular level which can be called as low grade inflammation. This type of inflammation is very important cause of metabolic diseases. Abhishyandi food increases the intra cellular fluids and deranges functions of cell. This type of food increases over all fluidity in the tissues which is termed as Kleda [7]. This can be compared with inflammatory food which creates faulty metabolism in Linolic acid and arachidonic acid pathway leading to inflammatory cascade. Many food stuffs which are supposed to be healthy are proven to be inflammatory adding on to the pathology of many diseases.

\section{Dramya Ahar}

One of the important branches of Ayurved is Rasayan which helps in restricting ageing. Many medicines along with life style and eating behavior had been advised to restrict ageing. Quotations are available which suggests certain food which hastens ageing effects. It has also been advised that people who live in cities and nearby places are unfit to undergo rasyan therapies as their life style and eating patterns are not favorable to elicit proper response. Charak samhita explains in rasayan Chapter that morbidity in human arises due to excess portion size, excess sour, saline, pungent, alkaline, dried vegetables, meat, sesame, sesame paste and preparation of (rice) flour, leguminous cereals, incompatible food, food those block micro channels of the body, unsuitable, dry and rough food, food that is decomposed, heavy for digestion, perished, and decayed food stuffs and food habits indulging irregular diet or eating while the previous food is undigested are all those causes which accelerates ageing. It is very important to explore the effects of such food on inner age of the tissue [8]. Effects of such food can be seen in the light of hormonal or cellular senescence as well less on immune system. This study can give a new vision to the branch of nutrition to restrict ageing.

\section{$>$ Malina Ahar}

The last category of food is Malina ahar. The word Malina clearly indicates that food which is along with the waste stuffs or the food which has become putrefied. We have seen that the above category of food has an impact on the physical health but Malina ahar has occurred regarding mental disorders in Charak Samhita. The word malina ahar has also occurred in the context and cause of delirium, pre coma and coma stage [9]. It definitely indicates that such type of food which is putrefied vitiates raja and tama property of mind and also lands the person into unconsciousness or some disorders regarding memory [10]. Research in such type of direction a definitely give us certain intimation regarding the causative factors in ageing disorders related memory loss. It's very important to promote dietary rules and regulations in ageing population and specially related to memory loss. The first task will be to define malina ahar and then its bio chemical impact like glycation or protein modification or Advanced glycation end products in the food which can be detrimental to tissues specially neurons.

\section{References}

1. Charak Samhita Sutra sthan $1 / 123$.

2. Charak samhita sutrasthan 25 .

3. Charak Samhita Viman sthan.

4. Kashyap Samhita.

5. Asthanga Sangraha.

6. Bhavprakash Purvakhanda Mishra varga 243.

7. Sushrut Samhita sutra sthan 21.

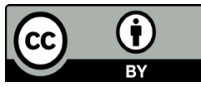

